\title{
An anthropological analysis about primatology - Reports of a particular human-animal relationship with Capuchin monkeys
}

\author{
ELIANE S. RAPCHAN ${ }^{1}$ and WALTER A. NEVES ${ }^{2}$
}

${ }^{1}$ Universidade Estadual de Maringá, Departamento de Ciências Sociais, Av. Colombo, 5790, Bloco G34, Zona 7, 87020-900 Maringá, PR, Brazil

${ }^{2}$ Universidade de São Paulo, Instituto de Estudos Avançados, Rua do Anfiteatro, 513, Butantã, 05508-060 São Paulo, SP, Brazil

Manuscript received on April 10, 2018; accepted for publication on June 14, 2018

\begin{abstract}
How to cite: RAPCHAN ES AND NEVES WA. 2019. An anthropological analysis about primatology - Reports of a particular human-animal relationship with Capuchin monkeys. An Acad Bras Cienc 91: e20180332. DOI. 10.1590/0001-3765201920180332.

Abstract: This ethnography is about a particular human-animal relationship based on primatological research on groups of wild robust capuchin monkeys living in Parque Estadual Carlos Botelho (Brazil), one of the largest preserved areas of Atlantic Tropical Forest in the world. It emphasizes the complex situations that highlight the difficulty of making this research. This space integrates administrative, scientific and local interests, producing a unique cartography. We reflect on the scientific research considering the relations among primatologist, field assistant and other animals and comparing it with the hunt. "Hunt" is a model inspired in techniques and in some aspects of recreational hunt to expand the comprehension of a complex routine defined to obtain behavior data.
\end{abstract}

Key words: Atlantic Tropical Forest, Ethnography, Ethnography of Science, Human-animal relations, Hunt.

\section{INTRODUCTION}

The study of non-human primates behavior is challenging because behavior is also a social phenomenon and it depends on variables not only defined by heritage with variation but also by environment, interactions, hierarchies and cognition. In the wild, the observation of the behavior suffers constant risk of interruption by factors ranging from the emergence of predators to invisibility of animals observed. Some types of vegetation or uneven lands can also offer more difficulties to primatological research.

Correspondence to: Eliane Sebeika Rapchan

E-mail: esrapchan@gmail.com

ORCid: https://orcid.org/0000-0003-1605-9886
The density of this intricate context can be accentuated if associated with other elements as, for example, environmental variations, local culture or the research type. For example, to observe wild macaques is quite different from observing laboratory experiments or even observing primates in extremely humanized environments. In the first case, the data are more likely but the researcher has less control over all the surrounding conditions. In the latter, the environment is artificial but the researcher has great control over all variables. There have been some experiments with wild primates (De Waal et al. 2005, Gruber et al. 2009) but the observation is the dominant procedure.

The complexity of behavior is enormous and the understanding of this can be expanded 
if analyzed from multiple perspectives which associate, for example, the obtained data with other factors, such as the potential bonds established between the researcher and the monkeys during the research time when they occupy common spaces for long periods of time. The complexity also can be associated with the anthropomorphism that, in its contemporary manifestations (Asquith 2011), potentially influences the researcher's point of view of the animal representations and classification.

The research on robust capuchin monkeys (family Cebidae known locally as macaco prego) in the Parque Estadual Carlos Botelho (PECB) is essentially observational. The capuchin are wild monkeys that inhabit an extensive area encompassing 459.79 square kilometers (Presotto 2009) within the city limits of São Miguel Arcanjo (São Paulo, Brazil). It is one of the last major remaining areas of Tropical Atlantic Forest (Mata Atlântica). Besides the robust capuchin monkey population (Sapajus nigritus) (2), approximately half of the critically endangered Wooly Spider monkey (Brachyteles arachnoides) population (approximately 600 individuals), (also named muriquis do sul or monocarvoeiro monkey by local population) of São Paulo State live there (Talebi and Lee 2010).

The Woolly Spider monkeys are only found in two other areas (the Mountain Range of Mantiqueira - Pindamonhangaba/São Paulo and Mountain Range of the Sea - Bertioga/ São Paulo) (Talebi and Lee 2010) and have been intensively studied in PECB. The Association Pró-Muriqui (www.promuriqui.org.br/site/en) is a non-governmental association that contributes to research, education and conservation and also has held some conferences and workshops such as the 3rd. Brazilian Course for Field Primatology in the PECB facilities in 2012.

The worldwide capuchin monkey population is comparatively larger than Woolly Spider monkeys. Its occurrence in South America is shown in the
Cebus distribution map (Lima et al. 2017). This map indicates the exclusive occurrence of Cebus in the PECB area. The research on robust capuchin monkeys that live in the Atlantic Forest focuses on aspects of social systems (Alfaro et al. 2012, Izar et al. 2012), spatial reference expressed by patterns of feeding and sleeping habits (Presotto and Izar 2010) and feeding ecology (Galetti and Pedroni 1994) (http://www.ip.usp.br/ethocebus/ ecspec.htm).

The number of people working at PECB is regulated and limited. Permission is only granted to administrative staff, security guards, forest police and researchers. The latter frequently have one research assistant (the locally named mateiro) and who spends much time within the PECB limits, according to authorization.

The first part of the ethnographic work in the PECB, made by Eliane Sebeika Rapchan, consisted of following one primatologist who was interested in foraging behavior of robust capuchin monkeys living in the park (Santos 2011). This behavior varies according to seasonal fluctuations (Fogaça 2009). By May, 2012, when the fieldwork began, the animals had less food available due to the reduced rains in autumn. In observational terms, this meant that the monkeys migrate frequently from one place to another, and to observe them, the primatologists must do the same.

We adopted the ethnographic observation since the first beginning of the work. Consequently, the primatologist was followed in this exhaustive task throughout the fieldwork. This experience gave us a strong impression that this kind of research is similar to some aspects of hunt, in many senses.

Many descriptive and analytical aspects of this work were strongly influenced by Tim Ingold (1994). He remembered us that, in Western thought, the concept of animal is always constructed under strong influences of emotional and intellectual prejudice. Animal, as category of thinking, always represents something that has minus positive 
attributes in relation to the human. His proposition is to think in terms of "animality" and "humanity" (Ingold 1994) that means to consider relations among them and the categories to what they pertain instead of classify them according to categories constructed that departing from predefined characteristics, identified or attributed.

In relation to what we have learned about primatological research realized on the behavior of capuchin monkeys in the Atlantic forest, Ingold's ideas help us to understand that the categories representing the animals are not ready and they are learned and constructed in a complex relationship of research. This work demands different and complementary kinds of knowledge. Among them the scientific knowledge brought to the field by the primatologist and the caipira knowledge brought by the research assistant. Thus, the results obtained are an elaborated expression of a lived experience. This experience is the product of a learning relationship between people, animals, and place in which "attention education" (Ingold 2000, 2001) is a central factor in understanding of the alive world where we live (Ingold 2011).

\section{MATERIALS AND METHODS}

THE PRIMATOLOGIST - AN ASTUTE FOLLOWER OF ANIMAL TRACKS

(...) “Almost always they've read the message in the ground correctly. The wildebeests or elands or okapis are where they thought, in the numbers and condition they estimated. The hunt is successful. Meat is carried back to the temporary camp. Everyone feasts." (Sagan 1997: 313).

The fieldwork done inside Carlos Botelho Park was made in 2012 with authorization of its responsible in the same conditions observed by primatological research in the area. The primatologists and the field assistant were informed about the characteristics of the anthropological observations and we stayed together in all activities of research during that period. We observed the same protocol followed by the primatologists and by field assistant in relation to the other animals and plants that live in the park.

There are aspects of this context that are relevant to understand the settings of the primatological and anthropological research that overlapped in the field work. First, the conditions to observe monkey behavior were marked by visual distance and by the constant effort to obtain data. Partnership and mutual aid between the primatologists and the field assistant were very important. The researcher's contact with the monkeys was always fast and fleeting because they spent most of the time in the top of the trees moving themselves through them.

Throughout a full day of observation, which began before sunrise and ends in the early hours of the night when monkeys seek their nests to sleep, the longest observation time occurs in the middle of the day when the temperature rises and the monkeys sleep after finding some food that temporarily satisfies them. During the rest of the day, the search for small portions of food scattered throughout the forest promotes constant displacement. Visual observations are often mediated by equipment, and the best clues to pursue are sounds and movements in the foliage.

Similarly, interactions between humans and monkeys are characterized by speed and fugacity. It is common to have an exchange of opinions between primatologist and field assistant to be sure about the name of the monkey observed, for example. It is through accumulated experience that the observations made under these conditions acquire density.

This field configuration contrasts with other ethnographic research records on capuchins (Rapchan and Neves 2016, Rapchan 2016) and muriquis (Sá 2005) in situations in which contact between humans and monkeys is prolonged and constant. In fact, the Ethocebus project developed in the cerrado region of southern Piauí on monkeys of 
the same species that inhabit PECB is characterized by variations in socioecology (Izar et al. 2012) and markedly different relationships between humans and monkeys (Rapchan and Neves 2016).

Secondly, the relationships established between primatologists, field assistants, and anthropologists involved mutual acceptance of those arduous research conditions, great readiness to teach, to explain, and to exchange impressions in brief moments when we could talk and share impressions about monkeys and about our feelings of exhaustion. The concern with the safety of the staff was also constant.

The difficulty in recording data on monkeys severely affected human relations because the search, pursuit, and efforts to capture the signs of monkeys left little time for more formal interactions and prolonged conversations during the day. At the night, when the daily research journey was over, we were very tired and there were still many things to do but we used to make dinner, talk and prepare the equipment that would be used in the next day of work.

These are some of the reasons why fieldwork in the Carlos Botelho Park gave us a strong impression of hunting in a literal but incomplete sense. Incomplete but sufficiently strong to promote identification among the primatologists. Maybe this sensation was been produced by the exclusive male presence (during the first phase of fieldwork we observed only primatologists who are men and the "mateiro" who was invariably a man). Or, on contrary, our sensation was produced by the strategies, movements and ways adopted to observe and to register the research data that mix feelings controlled anxiety, energy and adrenaline.

The observational pursuit of the monkeys by the primatologists is completely different from animal slaughter or confinement. Of course, this primatological observation is not a hunt but it is similar to one in all other senses because as in the hunt, there is learning, training and tactics indispensable to find the animal, to follow it, and stay as close as possible to it. And this entire apparatus is used exclusively for scientific observation.

The ethnographic description that follows intends to offer sufficient elements that justify this metaphorical use and provide to the reader an approximation, as intense as possible, to the kind of human-animal relation established in this highly particular context.

Ethnographies that consider the importance of the relations among humans and other animals express recent transformations in anthropology from displacements resulting from criticism of anthropocentrism. In spite of the records on the symbolic presence of animals in totems, cults, myths and language (Descola 1975, Durkheim 1989, Evans-Pritchard 1940/1969, Lienhardt 1978, Leach 1964, Lévi-Strauss 1962, Tambiah 1969) and activities as hunting, fishing, and breeding (Harris 1989, Rappaport 1968/2000, Sahlins 1979) since the earliest anthropological work, approaches that consider the multiple levels of relationships among humans and other animals from a relational perspectives are much more recent (Carrithers et al. 2011, González-Abrisketa and Carro-Ripalda 2016, Kohn 2007, Lestel 2014, Silveira 2016, Tola 2016, Varela 2015).

In relation to the field surveys that contemplate the great apes, it should be noted that the primatologists Jane Goodall and Barbara Smuts also have produced a relevant impact. The narratives produced by both have fundamentally changed the scientific descriptions of primates because they have brought to the public, among other things, contexts full of life stories, complex relationships, subtle behaviors, conflicts, names and affections.

Although the Goodall (1971/2010) and Smuts $(1985 / 2009)$ styles did not characterize the pattern of descriptions in primatology, they stimulated reflections and inaugurated new ways of thinking about humans and other primates while expressing aspects of research relationships 
involving scientists, and other animals that have affected certain points of view of anthropology (Durham 2003, Rapchan and Neves 2005). Lestel's propositions (2008) about "hybrid communities" made up of humans and other animals are also part of this process.

There are many ways to classify and analyze the hunt. Two of them are related to this ethnographic work: the comparative similarities between scientists and modern hunters in a association between scientific persecution and hunting of animals.

The word "hunt" refers simultaneously to the predatory hunt and to the hunt as a sociocultural practice. Despite the predatory hunt could be also defined as a recreational practice (Gamborg et al. 2018) it is frequently in conflict with conservationist positions and ethical reflections on animals (Beauchamp and Frey 2011, Gruen 2011, Wiafe 2018). A primatologist who practices recreational or predatory hunting is, nowadays, an aberration.

But, on the other hand, the hunt as an extremely elaborate set of practices has already been compared with research work (Sagan 1997). Sagan (1997, 313-15) emphasized that the !Kung-San, huntergatherer people of the Kalahari Desert (Lee and De Vore 1968/1999, Lee 1992) combined information and knowledge obtained by socialization with careful observation of specific evidence and indirect information in each particular situation to achieve a successful hunt in the desert.

Taking the relationships between humans and other animals, Cartmill (1993) analyzes the history of hunting, this practice in which humans kill other animals, trying not to reduce it to "the perfect type of that pure evil which metaphysicians sometimes have sought"(Cartmill 1993, 228). However, he concludes that, from the Western perspective, hunting is an "armed confrontation between humanness and wildness, between culture and nature" (Cartmill 1993, 30).
On the other hand, Kwon (1998), when analyzing Orochon reindeer hunting practices in eastern Siberia, argues that even hunting by populations whose organization is based on modernity principles can not be reduced to a narrow notion of predation. Recent works highlight the interest in ethnographic research on hunting as a sport and reinforce Kwon's perspective. For example, Hoerig (2017) produces an ethnographic record of Lutheran shepherds / hunters in Texas who met annually (between 1984 and 2007) to hunt white-tailed deer during the hunting season. The text explores the place of hunting in Christian theology and notes that the gathering to hunt offers clergymen the opportunity to escape the social pressures related to their functions.

In Montana, Eliason (2008) noted a striking distinction between elk resident hunters and nonresident hunters. According to him, non-resident hunters and therefore unrelated to local nature and society, are much more likely and interested "to seek trophy-class animals."

On the other hand, science, at least in its modern version (Latour 1994/2008), seeks to construct a rational, orderly, logical and conceptually reproducible world. Hunting, at least in its sporting expression, only adds pleasure if it can reverse the asymmetrical power relations established between humans and animals (Dahles 1993). And it is his ambivalent expression that makes it so repulsive and so attractive to our culture.

In relation to the specific case of the primatological research carried out in the PECB, the comparison between the research and the hunting suggests how much the strategies adopted to carry out fieldwork in the PECB transpose, in an exemplary way, the conventions about the control exerted by rationality in modern science and, in many instances, subvert relationships to the point, as the field helper put it: "Here, we have to do what the monkeys want." 
Ingold (2000) returned to the hunt as an anthropological subject emphasizing its transitional, complex and complementary meanings. There is no rigid frontiers between nature and culture:

As with many other hunting people around the world, the Cree draw a parallel between the pursuit of animals and the seduction of young women, and liken killing to sexual intercourse. In this light, killing appears not as a termination of life but as an act that is critical to its regeneration. (Ingold 2000, 13).

At certain moments while hunting of caribou, a wolf stops and looks in the animal's direction. According to biologists, this behavior gives an additional pause for breath to the predator and to the prey before the end of the hunt. When pursued by human hunters, the animal adopts a similar behavior, but differing from wolves, humans have a great advantage in this situation and the result of the hunt is favorable to the hunter.

Sami and Cree people interpret this behavior as a loving and sexual gift. They believe that caribou give themselves to the hunters. From the anthropological conventions perspective, the behaviors, meanings and symbols involved in the traditional hunt are exclusively humanized cultural expressions. Ingold's analysis emphasizes the necessary fusion of multiple variables in this complex relation to comprehend it. There is no separate nature nor culture. They are simultaneous and inseparable. They constitute a singular whole (Ingold 2000,14).

The pursuit of capuchin monkeys to observe their behavior in PECB analyzed from an ethnographic perspective is similar to the complexity of the Cree relationship with the caribou. The unity formed by monkeys behavior, their relations with the environment and the researcher's behavior makes possible this primatological observation.

The primatologist pursues the capuchin monkeys to observe them for lengthy periods and as closely as possible. The details are vital to this kind of research. It is pain-staking and laborious, work but it only takes place because the monkeys accept the human presence and human observation. At the same time, all this happens on their terms, according to the monkeys habits and in their place. Living in a tropical forest, the monkeys spend most of their time in high trees foraging, sleeping, playing, grooming, taking care of their offspring or copulating. They tolerate the human presence but also they keep a safe distance between humans and monkeys.

The anthropologist's presence was promptly accepted by the primatologist, which is not the rule (for an anthropological analysis of a different ethnographic experience with primatologists see Sá 2005). The same happens with almost all monkey groups. We observed that the individuals of the more stable groups demonstrate indifference to an stranger presence, whereas the members of the most unstable group, using a very anthropomorphizing expression, appeared to be more apprehensive than at ease (Nakai 2007).

We observed that the monkeys of the unstable group vocalized more and moved from one branch to another more frequently in a full fruit tree that other more socially stable group. The primatologist that we observed also reported a higher level of agitation among the monkeys, but he was unsure if this behavior was related to our presence or to the instability of social boundaries of the group.

Therefore, the adoption and reinvention of the term "hunt" to explain the research conditions and the relation between humans and monkeys in this specific research context aimed to offer density to the description to this challenging and fascinating experience. Primatologists do literally hunt monkeys - but they do not aprisionate nor kill them. And like the hunters in the forest, they follow them patiently. They hear them, follow their tracks, search for them in the dense forest, and they learn their habits. In fact, primatologists seek the rare 
opportunity to observe the monkeys and to obtain more data about their behavior.

The complex web of relations is essential to make primatological research as observed in the park correspond metaphorically to the hunt, a hunt without prey. The necessary training, the logistics, the method and the techniques to register the data are part of the work in the same way that the physical exhaustion, the doubts and the surprise precede the discovery. The whole situation is similar to some ethnographic reports of technical aspects of indigenous hunts (Lima 1996, 21-22).

The prize is the data, the information and the opportunity to observe. The dense forest, the slippery, steep-sloped and irregular terrain, the high humidity, the lengthy and time-consuming diary entries that begin with the dawn, when the monkeys wake up, and finished one or two hours after dusk, after the monkeys sleep: all of this renders the research work arduous and difficult. But it is also a stimulating challenge.

It is also important to point out that ethnographic research in this context is as difficult as primatological research. To follow the primatologists in his/her observation and, at the same time, to make the ethnographic observation itself is a great challenge. Consequently, the results presented are modest and incomplete. It will be necessary to do more fieldwork in the future. However, the ethnographic material collected thus far is sufficient to delineate some central aspects of a certain kind of relationship established between monkeys and primatologists in this specific environment.

\section{DISCUSSION}

CARTOGRAPHIES OF ATLANTIC FOREST - THE STATE, THE SCIENTISTS AND THE LOCAL CULTURE

The first impression of PECB as a pristine wilderness quickly fades when one stays within the park for a longer period. Luxurious vegetation covers this immense and considerably preserved natural area in which it is possible to observe the passage from cultivated fields to secondary vegetation to the forest. However, the dense vegetation hides a great deal of human impact and different types of human interactions with the diverse animals that live in the park.

The PECB is one of four areas of preserved Atlantic Forest (Mata Atlantica) located in the Serra de Paranapiacaba in São Paulo State (Brazil). The forest reserve was founded in 1941 and in 1982 it was transformed into a State Park that is maintained and controlled by the government of São Paulo State. Since 1991 UNESCO has recognized this area as a World Heritage Site.

The municipality of São Miguel Arcanjo has 31.452 inhabitants (IBGE 2010). The economic activities of the local population include cultivation of grapes, and in minor proportion potatoes, soy and beans on small family-farms, as well as services and small-scale commerce (IBGE 2010). The rural farming activities are also associated with a way of life typical of some Brazilian regions whose communities practice what is known as caipira culture as described by a vaste socioanthropological literature (Brandão 1983, Ferreira 2008, Moura 1978, Queiroz 1973, 1983, Ribeiro 2008, Souza 1974).

The so-called "traditional populations", according to the legislation and public policy programs in Brazil (Brasil 2007), represent a great diversity in relation to the use and occupation of space, the appropriation of natural resources and the reproduction of socio-cultural, religious, economic and aesthetic aspects that constitute knowledge and practices in relation to land, water and other resources. This diversity, however, also expresses a counterpoint to the great ownership of land.

These populations usually receive adjectives that express the exclusion and social subordination to which they have historically been subjected 
since the slave period (Queiroz 1973). Such negative expressions have been used throughout the abolition of slavery to the reception of about two million poor or miserable peasants who arrived from Europe and from Japan to the south-east and south of the country from the mid-nineteenth century.

"Traditional, archaic, rustic, tardy, backward, inferior and submissive" (de David 2017, 77 [translated from Portuguese]) are the pejorative terms often used as reference to the inhabitants of the Brazilian rural world based on the asymmetry of access to land. Thus, such socio-cultural diversity is homogenized in poverty and subaltern condition: Even producing much of the food consumed in the country, the peasant has long been treated by science, literature, and politics as lazy, retarded, and indolent. (de David 2017, 77 [translated from Portuguese]).

Such socio-historical conditions have favored the disappearance of the caipira culture as a way of life. Nevertheless, despite that, the community still carries on some caipira cultural practices, including collecting the fruit of palmito-juçara (Euterpe edulis Martius) from palm tree (also locally known as içara, juçara or jiçara) and hunting small mammals and birds where is allowed. The latter hunting-gathering foraging activities are particularly important here because they are not only foraging and socio-ecological activities, but also practices that are forbidden inside the park. They frequently complement foraging activities of poor family farmers. The hunting of small game animals using artisan traps is very common. Boys learn to hunt in their early years using slingshots.

The park protects the animals that live there, which is also the case for vegetable species as, for example the juçara. It is prohibited to hunt there in general, as well as to gather juçara too because it is in danger of extinction. The palm tree has high economic value and is widely consumed by humans. But the unregulated and illegal harvesting and exploitation has put the species in danger. Since the park was created, the forest police have continuously monitored to prohibit and punish hunting and the gathering of juçara.

Laws and policies supporting endangered species protection associated with the promotion of ecological characteristics of the park as a common patrimony encourage some particular behaviors among the local population. When talking informally about the park, many local inhabitants appear proud to live in the city near the park. Some of them, such as bus drivers, mateiros and their families, workers of the park, people who live or study around the park (there is a school on the border of the road that is used to arriving at the main entrance to the park), indeed affirm that the behavior of the population in relation to hunting wild animals and gathering juçara has changed. According to them, most of local people, predominately males, no longer practice huntinggathering, including the boys.

More data is needed to evaluate these claims. Nonetheless, it is possible to make two statements about them: 1) the change of the discourse about hunting-gathering of wild species, from a positive to a negative value, can influence values and tendencies of future behavior and 2) if the boys of next generations really do not practice huntinggathering of wild local species, it is possible that something will change. But it really requires future research to monitor and confirm these trends.

The local population also visits areas along the boundaries of the PECB for recreation. These areas are small plots of land around the Taquaral River banks. While visitors can play inside or outside water, swim, have picnics and barbecues. On the weekends, these installations host lots of people, families or groups of young people, to spend their free time.

Other boundaries in the space are determined by the PECB administration around and inside the park. There are control installations at all 
gates and the entrance and exit of people are regularly controlled by security guards. The building that hosts researchers is near the main gate. This configuration facilitates research, such as the control of the activities inside the park. The administration is also responsible for monitoring roads and access ways inside the park. Fences indicate the official boundary of the park and the control of human entry.

Visitors are required to schedule hiking on trails with monitors. One of them, the Taquaral River Trail, has displays with information about tree species denomination. The trail of Açude shows signs of transitions from cultivated fields, passing to secondary vegetation and native flora. When walking there, visitors can see some animals that live in the park or, at least, find their tracks in the muddy soil on the border of the dam.

Animals, on the other hand, do not recognize boundaries and cross the park frontiers through roads, trails, camps and fields next to the PECB. The administration has perceived this animal dynamic and since the last decade has adopted the ecological "continuum" concept. This implies that the park administration acts in favor of integrating the animal areas for grazing and roaming, which have the same natural characteristics of a neighborhood, negotiating the possibility, for example, of eliminating fences and involving the local population in favor of ecological education and conservation.

The forest police guard the roads inside the PECB to prevent hunting, gathering or removal of wood, all of which are illegal actions, and they also arrest offenders. Frequently, the forest police act together with the park employees and monitor the same roads with them.

In addition to the capuchin monkeys and Woolly Spider monkeys, there are other animal species living in the park. There are 220 bird species registered but it is suspected that this number could reach 400 species. Tapirs (Tapirus terrestris), jaguars (Panthera onca), bush dogs (Speothos venaticus) and snakes (Serpentes) have been previously sighted there.

The researchers who have authorization to work inside the park have their projects approved by a council. Just as the animals leave their tracks, and the park staff leave footprints, scientists also leave their marks on the landscape. They are subtle, but visible. There are many types of research interventions in the park area.

For example, one can come across little square areas of 3 or 4 square meters delineated by strings or plastic tape. Colorful pink, blue, red, yellow plastic markers, fixed on the trunk of trees mark trails or offer information related to some specific data collected for some research such as the date when a given tree was used by the monkeys for sleeping or for feeding. This includes biomass collectors and camera traps that detect movement and register images of animals and, eventually, of humans.

There are also some metal cages installed to capture large predators such as jaguars. The aim of installing these devices was to facilitate collecting blood, urine and other fluids to examine. But, according to our informants, no jaguar was ever captured, so the researchers have abandoned this work and the cages; now some remnants remain there.

All equipment leaves marks of scientific intervention on the landscape, which are left there even when the research is finished or when it is interrupted. These marks suggest a cartography of research. They are human interventions in nature. These are strange objects installed in the park with the function of contributing to the scientists' efforts to understand the natural world. In this context, nature is frequently conceived as another domain, an alterity, another world.

Another important human group, despite being small, is the field assistants or mateiros. They also can remain long periods inside the park with the 
function of supporting scientific research. They are members of the local population, always men, workers who have collaborated with researchers from the beginning of scientific activity in the PECB. They are often hired to work on a project and help groups of researchers to obtain their research data.

They clear the tracks and keep them clean and safe. They have great knowledge about the entire region, which helps the researchers find their way around the park, which is very important for collecting data. Information about location is important to find and to follow the monkeys and, at the end of day, to return safely to the research base because it is incredibly easy to get lost in the forest. They are also trained to work with primatologists and collect data.

To observe the animals in the park, scientists also traverse through the non-demarcated trails. And all the time, the scientists traverse the park area with the aid of the mateiros. So, the mateiros develop their work in constant and intense contact with researchers, and this stimulates a strong empathy among the mateiros, the animals and the forest. This behavior cultivates an environmentalist ethos and conduct verified in scientist and research assistant.

Considering their local origins, their social class and their cultural references, the mateiros were born and live surrounded by references of the previously mentioned caipira culture whose remnants are dispersed throughout many areas of the interior of Brazil (Souza 1974). This means that, as with all other boys who grew up together there, the mateiros learned to swim in rivers, to climb trees, to pick fruits and to use slingshots to hunt small animals. These were the activities of their childhood.

However, the mateiros hunt neither when working with the researchers, nor when they are outside of work. They do not practice predatory, recreational nor traditional hunting. On the contrary, they protect and many times they save animals from danger. At same time, they modify and they are affected by these two worlds. They know how to hunt, they know how to take the juçara, but they do not do this in the park. They learn with the scientists how they should behave when they are inside the park. For example, they do not leave seeds, peels, barks and scraps after taking their meals to not impact the balance of the forest. But they also teach to primatologists how to move inside the forest and how to read its signals.

The park is an impressive unit dominating the landscape. At the same time, it is distinguished from this same landscape, the internal world that exists inside the park is, at same time, demarcated and fluid, simultaneously different from the exterior and similar to the surrounds. It exists in itself and it is simultaneously inside and outside the human domain. It is a part of nature that must be protected from human intervention. It was artificially created but it appears as a vibrant and living entity.

The park also has, to a certain degree, an artificial existence, but it also ensures that this lush universe is defended and preserved. This immense part of nature is dependent upon the actions of humans to exist. Ironically, which can be so fragile and yet sometimes such a destructive species, is now essential to protect this endangered enclave of nature.

Human action also has transformed the park into an immense source of scientific knowledge. PECB is, from a scientific perspective, a colossal open sky laboratory.

\section{CARTOGRAPHIES OF PRIMATOLOGY}

Despite the worldwide impact of reports of stone tool use by wild robust capuchin monkeys living in scrub lands, those living in tropical forests have not been reported to use tools to obtain food (Spagnoletti et al. 2012). Long-term studies have been done in PECB since 2001 by the primatologist Patricia Izar 
and her students, including the research observed in this ethnographic fieldwork, but there has been no recorded observation of tool use in the forest.

Santos (2011), for example, explores the hypothesis that greater quantities of nutritionally richer food is consumed by robust capuchin monkeys in the Boa Vista Farm (a scrub land region of northeastern Brazil) than in PECB. At the same time, the nuts found there need to be processed by tools to be consumed.

To gather field data on foraging and nutritional parameters of robust capuchin monkeys diet (Santos 2011) in PECB, the primatologists follow and observe the groups every day from when the monkeys wake up at sunrise to sunset, throughout the year. The monkeys' movement in tropical forests is arboreal. They move rapidly across the canopy of trees. The ability to track the monkeys from the shortest possible distance and as continuously as possible are indispensable skills for doing this kind of research.

The mateiros are also indispensable for accomplishing this task. One of the more experienced mateiros, who has worked in primatological projects developed in PECB for more than ten years, drew maps that turned into some of the more commonly used tools by researchers and mateiros working inside the PECB.

These maps are very important because they serve as reference and orientation to researchers observing creatures who obviously do not obey the human trails and roads. Using these maps, researchers are able to return to known places and departing from there to return safely to their accommodations or to mark paths that can be used for continuing the observation of the monkeys when it is interrupted. To not lose the opportunity of observing the monkeys, the primatologists traverse dense vegetation crossing over, through or alongside bushes, logs, fallen branches or huge plant leaves, covering immense areas of 200 square meters or more where there are no trails.
Considering seasonal changes, sometimes the task of observing the monkeys becomes even more difficult due to rain in the rainy season. When it is raining, the visibility decreases and frequently the primatologists lose sight of the monkeys. When this occurs, the possibility of losing the monkeys' path is greater. At the same time, it is possible that the rain affects robust capuchin monkey behavior. There is a research in course about the effect of rainfall on the locomotion capacity of the monkeys (Delval et al. 2017).

Rain also renders observation more difficult. The air humidity is very high throughout the year, and it rains after a 5 to 7-day dry-intervals in the dry season (from April to September). The intense rainy season (from September to April) reduces the dry-intervals to 1 to 2 days before another strong rainy period.

To find the ideal opportunity for observing monkey behavior, in such challenging conditions, it is necessary to be patient, have stamina and a great deal of perseverance. Research training and a good methodological orientation are required as well as motivation since the animals are frequently 4 to 7 meters above the ground in the higher trees.

Considering that direct observation is not an easy task, binoculars are an important but not an exclusive resource to do research. Primatologists also try to obtain auditory information (vocalization, shaking of trees and rustling of leaves) or secondary visual material (for example, seeds of fruits that drop on the ground when monkeys eat them). They are secondary but also important in providing a more thorough picture of the animals behaviors.

Indeed, reality is much more diverse and complex and the scientist makes a great effort to reach the knowledge as fully as possible, but it is always a limited attempt, and the access to everything remains incomplete:

(...) "scientific method is based on the reduction of complexity. The world is complex and the human mind can not comprehend it completely. Knowing 
means to separate and to classify to after be able to determine systematic relations among which was partitioned." (Santos 1998, 28. translated from Portuguese).

The primatologists move around the forest to obtain information about the monkeys' behavior. The monkeys do not conform to the human ways of moving along paths. So the researchers use various strategies to find the monkeys in the forest and find the best way not to lose them.

To do this, researchers mark the trees where robust capuchin monkeys sleep. They use Global Positioning System (GPS) and the trail map, previously mentioned, to mark this place. The challenge is not to lose sight of the monkeys all day long and to repeat the same strategy the next day. When primatologists lose all signs of proximity of the monkeys (visual contact, vocalization or characteristic noise) that indicate their presence, they enlist the mateiro's help to find the monkeys again.

Trees where robust capuchin monkeys were previously observed sleeping or foraging are marked with colorful plastic tape (also previously mentioned). This information is useful for the research and also offers some orientation to the researcher when finding other monkey groups is necessary. All these markings show that despite the aspect of being in a complete wilderness plot defined by the park borders, the primatological research also leaves its mark within. They are subtle, but very cultural, and essential to the research.

Research inside the forest is difficult and also dangerous. Someone can be seriously injured or break a limb, which makes the already difficult movement inside the forest an even greater challenge. This is one important reason for the cooperative work between the primatologists and mateiros. They coexist and depend on each other. They constitute a unit. But, despite the cooperation in the work of collecting data, searching for monkeys to observe, and generally finding their way through the park, primatologists and mateiros are different people. Not only because they are two uniquely different individuals but also because they are diverse socio-cultural beings who influence each other since they started work together.

The primatologists and mateiros share a conservationist attitude and empathy with the monkeys, the landscape and nature. However, great differences emerge in relation to knowledge. Local knowledge and scientific knowledge are different. Primatologists and mateiros were trained to behave in the forest in different ways. The mateiro was socialized in a particular culture, that pertain to a great and disperse tradition known as caipira culture and he express a local way of life and a singular relation with land, nature and time. The primatologists obtained scientific training that connects them with the universalistic principles of science and with other primatologists who do research in PECB. Both, together, face the challenges of collecting data on the monkeys in that forest.

Despite their differences, the mateiros and primatologists must frequently discuss evidence, signs, sounds and tracks. They frequently exchange views and impressions before making a decision. They also exchange information. They frequently make jokes about animals and risks. For example, the mateiro systematically uses the expression "solitary male" instead of "peripheral male". The scientific term is "peripheral male" because the monkey can integrate a group when the fission phenomena occur. The monkey is not alone all the time. The mateiro, talks as if the monkey were a single and explains: "Excuse-me, I am a caipira" ${ }^{1}$. The mateiro means that he does not have scientific knowledge, he does not know how to talk using scientific words; he is a simple person. And both laugh.

\footnotetext{
${ }^{1}$ Caipira is the name of a sociocultural specific way of rural live in Brazil. Its always associated to family agricultural work and small extensions of land. Caipira is also a symbolic, ideological form to represent rural people in Brasil. It is correlate to other forms of rural life as "camponês", "caboclo", "caipira", "roceiro", "sertanejo", "capiau” (Brandão 1983, 2).
} 
However, sometimes, they also argue. We had the opportunity to witness one of these conflicts. While a primatologist was observing a group of monkeys foraging, a mateiro started to follow the first member of this group that were going to another place. The entire group of monkeys had gone to the road and stayed there.

The mateiro reported enthusiastically by radio that the monkeys were eating a fruit not previously reported in their diet. According to him, they were eating all the fruit parts and discarding only the seeds. So, he began to collect the seeds for the primatologist to analyze later.

The primatologist disagreed with the mateiro's account. So, when the last monkey left the fruit tree heading to the road, the primatologist did the same. This is another cooperative strategy of work adopted by this couple not to lose sight of the group of monkeys being observed.

Upon arriving at the road, the primatologist took the seed, smelled it, peeled it, and broke it open. So he showed it to mateiro and told him that it was a seed of grude (local denomination in Portuguese), which is a little fruit from the family of jabuticaba also known as Brazilian Grape Tree (Myrciaria cauliflora). He also said that the monkeys were not digesting the fruit but defecating it. The mateiro was embarrassed. For the rest of the day, they almost did not talk. They finally resolved this conflict at the end of the day. Nonetheless, they solved their conflict and started the next day working together again.

MATERIAL CULTURE, BODY CONSTRUCTION, LOGISTIC, ROUTINE, METHODS AND TECHNIQUES: ASPECTS OF PRIMATOLOGICAL RESEARCH TO AN UNCOMMON DAY-BY-DAY

To obtain the fieldwork data needed for the research at $\mathrm{PECB}$, the primatologist has to be able to recognize individuals and groups, as precisely as possible, and he also needs to master techniques and strategies of work. To do primatological research related to foraging behavior it is important that the primatologist has all previous known information about the food that comprise the robust capuchin monkey diet and location of their sources.

Primatologists also need to learn how to perceive and translate signs uncovered in the forest: movement of branches in fruit trees used for foraging, sounds related of consuming food, such as water falling from Bromelia leaves, sounds of seeds, peel and husks that fall from high trees or the din of fibers being torn apart. It is important to be able to identify the places previously visited by monkeys for foraging.

Visibility is low in tropical forests and the close cooperative relation and mutual dependence between primatologists and mateiros who work at PECB promotes the production of multiple work strategies. For example, they use radios frequently but whistles as well.

Trust is also essential in the work relation between primatologists and mateiros. Monkeys are agile and the strategies used to follow them inside the forest require precise and rapid exchange of information about the monkeys location and behavior as well as additional information that can contribute to anticipating the next route of monkeys. For example, when Woolly Spider monkeys are moving in a certain direction, it is presumable that robust capuchin monkeys will take another distant route since Woolly Spider monkeys are bigger than robust capuchin monkeys and the latter tend to avoid the former.

Primatological research work also has an important physical component. It is necessary to avoid being loud, and to hike uninterruptedly for periods of 5 to 7 days. For example, the mateiro who is currently working on the project is an exmarathoner. During fieldwork intervals, he runs, walks or bikes 20 to $180 \mathrm{~km}$. The primatologist also runs, lifts weights, and boxes during the research intervals. 
There is also a set of indispensable materials needed to do primatological research in the park, which can be described as material culture. Clothes are particularly important. Fast-drying cloth pants are useful in a region with high levels of relative humidity and, shirts and blouses with long sleeves protect the arms from injuries. Rubber galoshes used by tractor drivers in Brazil are used by both the mateiros and primatologists. Clothing for protecting the head and neck, such as scarves and hats is equally important. Raincoats, waterproof flashlights, radio transmitters, canteens, insect repellent, food (lunch and snacks) and first-aid kits are indispensable items.

Despite that the primatologists and mateiros use different kinds of medicine, for muscle aches and headaches the former and for skin wounds, cuts and the latter for punctures, both experience many aches and pains, and both require conventional drugs.

Carried food items also express subtle differences of taste, habits and necessities. And, ironically, despite that this is a project about foraging behavior, during a fieldwork research day, there is little time to stop and eat. The monkeys, in contrast, search for food tirelessly from early in the morning, when they wake up, until sleep time. Human necessities are defined in relation to animal necessities and behaviors.

During short intervals, frequently of 30 or 40 minutes when the monkeys find an abundant fruit tree or when they are resting, the research team eats. Lunch items are frequently the same but snacks are quite different. The mateiro prefers peanuts, fresh fruits and marmalade, which are common in caipira diet. Primatologists prefer chocolate and cereal bars, snacks frequently consumed by students and people with urban habits.

The objects found inside backpacks are sometimes different too. The primatologist carries binoculars, a penknife, GPS, a pencil, a conventional notepad as well as a waterproof one. The mateiro carries a knife, a machete and a rope.
All the tools are complementary; these objects are selected cooperatively and are needed to support the primatological research done at PECB.

The primatologists researching robust capuchin monkey behavior work in a house near the park. This building was originally constructed to be an inn to house tourists expected to visit the area, but not that many tourist came. Next, it was transformed into a restaurant. All these commercial initiatives failed. Now, the house is rented to the research project staff.

There is always at least one primatologist working in park throughout the year, focusing on robust capuchin monkey behavior. The work routine period of the researchers is of 7 to 10 consecutive days dedicated to the fieldwork and 5 days for doing other activities, successively. The same for the mateiro. Sometimes, according to the necessities of research, the primatologist changes the routine to 5 days for fieldwork and 2 days for other activities (data organization, lectures, institutional contacts etc.).

The fieldwork day starts early, an hour before sunrise and also before the monkeys wake up. After preparing and having breakfast together, each staff member organizes the necessary items to carry on a long research day.

The fieldwork day finishes only after the researcher "puts the monkeys to sleep". This expression is frequently used by all persons who know the primatologists' routines. This means that the researcher only leaves the park after the monkeys sleep and after registering the place where it happens. This occurs 15 to 30 minutes after sundown. This practice is important because it ensures that the researchers will be able to easily gather data the next day (Fogaça 2009). Sometimes it fails, but all efforts are made to avoid this.

The same holds for resting and sleeping as well as having meals: the research staff only discontinues research activity when the monkeys are sleeping at night. Only then, do they take 
showers, talk, listen to music and take their dinner. This is also the time to organize and pack samples to be sent for biochemical analysis or to repair equipment if necessary, for example, to sharpen knives and machetes. This is the time to rest and rejuvenate for another work day.

The expertise needed for this research requires training. The pioneering work of Patricia Izar in the 1990s developed many general techniques for collecting data that continue to be used in addition to other innovations. She trains her students to work in the park, and those who have more experience also help the beginners. They train the next generation of researchers to deal with the challenges of fieldwork in primatological research at PECB.

For example, foraging behavior research uses a technique named "scan sampling". The information registered is about frequency of feeding, kind and characteristics of food consumed (flower, fruit, stalk, bud, insects, parts of small animals) and where it was obtained (species of tree, location, etc.). The trees are also tagged with information on GPS position, trunk diameter, which part of the fruit that was consumed, the date when the entry was made and which monkey group was the consumer. The primatologist also records a great deal of information comprised of traces, rare or episodic behaviors, and fragments which may be useful in future analyses.

\footnotetext{
2 "method of sweeping (scan sampling) sampling consists of writing down the activity accomplished by each member of the group in an interval of predetermined time (Setz 1991, Colling 1993). The observation is accomplished for 1 minute to intervals of 5 minutes during the whole time of contact with the group. In the sweeping, the visualized individuals' identity is registered, as well as the activity (foraging, displacement, rest and other) and the consumed (base of the rosette of Bromelias, spineless, fruits, leaves, flowers and other) alimentary item. The consumption of invertebrate animals is discriminated as: spineless in Bromelias, spineless in branches, spineless in leaves, spineless in other." (translated from Portuguese, Fogaça 2009, 13).
}

Local conditions offer a distance between monkeys and primatologists that has a double meaning: they are out of sight and are far from contact with humans. To a certain degree, the robust capuchin monkeys that live in PECB are always distant. They spend almost all of their time sleeping or awake on the top of the trees. In most periods of wakefulness, humans can only see them from far. It is always a distant view. At the same time, the opportunities to observe the monkeys are rare. In tropical forests it is not uncommon that primatologists spend weeks without seeing any monkey.

From a certain perspective, the robust capuchin monkeys that live in the park are considered more "authentic" by the primatologists because their contact with humans is less intense than in other environments as, for example, in the scrub land region. They are always far from human direct contact.

At Boa Vista Farm (State of Piauí/Brazil) (Izar et al. 2012, Alfaro et al. 2012), where some of the primatologists who do research at PECB also do comparative studies, the environment and behaviors are different, and the robust capuchin monkeys have a predominately terrestrial behavior. Consequently, they stay in closer proximity to human sight and touch. The interaction between human and animal is quite different from what occurs in PECB.

At Boa Vista Farm, it is common that humans and monkeys have face-to-face encounters. The vegetation in Boa Vista farm is sparse and the trees are lower in height; also the bushes of the undergrowth are gnarled and thorny and produce nuts, and the soil is dry and the temperatures are higher than in PECB. Frequently robust capuchin monkeys are seen on the ground in Boa Vista Farm.

The habituation of monkeys with an unknown human is slower in the scrub land than in forest. Perhaps the monkeys at the top of the trees do not consider a human 5 meters below to be dangerous. At PECB the monkeys know that humans are among them but, apparently they do not perceive 
any kind of direct or relevant behavior from the humans as observed in their social relations. And this statement is valid for me and for the other humans who study them. In other words, from the monkey's point of view, humans seem to be an innocuous part of the environment. They are perceived but there are no direct interactions, no cooperation, no predation, nor competition.

From the human perspective everything is different. Researchers and mateiros are there exclusively to observe the monkeys. They spend the entire day doing this or trying to do this. This is their only objective. They use all their senses to reach the monkeys. As hunters they look ahead, hear, pursue and patiently wait for the opportunity to observe.

A different situation is observed when robust capuchin monkeys encounter Woolly Spider monkeys in the forest. There is no predation between them but the Muriquis are bigger, stronger, and have brachial movements and they share some common foraging trees with the capuchin. They compete for some kinds of food. When they encounter other capuchins, they screech loudly and disperse very quickly.

This is frequently a tragedy to the primatologist who is following them. When this happens the researcher is reduced to wandering the forest, roads and trails listening attentively for some vocalization or noise, searching intently for some trace to begin his/her work of observation again. Sometimes he/ she will spend many hours or even days before finding the monkeys again. Sometimes it rains and the things turn worse.

RESEARCH IN WILDERNESS AREAS: EXTREME CONDITIONS AND SENSIBLE RELATIONS OR WHY HUNTING IS A GOOD WORD FOR PRIMATOLOGICAL RESEARCH IN ATLANTIC FOREST?

Our intention here is to bring the reflections of the anthropology of the working practices of the field of primatology performed in a given context. This will allow us to reflect on these research practices as phenomena that not only transcend what canonically expected of relations between researcher and object as also encompass complexities overflowing the borders of relations between the researcher and its object. This does not mean that we want to criticize primatology made in field pointing its limits, but corresponds to suggest that approximations between anthropology and primatology, in methodological and analytical terms, can produce relevant dialogs and enrich the results obtained.

The seasonality and the intense and multiple relations with nature (Ingold 2000) are relevant characteristics of many human cultures: fishers, peasants, hunter-gatherers and others. As with them, primatologists are subjected to seasonality while developing their tasks. The amount and the types of available foods influence the displacement flows and the paths of the monkeys living in the Atlantic forest, and all this directly affects the dynamics of primatological fieldwork.

The delicate relation established between primatologists and primates in this specific environment also deeply depends on natural equilibrium. This kind of primatological research needs specific natural conditions in which techniques, tools and social relations are intrinsically related to achieve results. At the same time, these primatologists and the robust capuchin monkeys need natural conditions of the park to be preserved. Without such support, this specific kind of primatological research will disappear.

The same is true for the techniques and strategies of research extremely specialized to the conditions of the park, the dependence of mateiro's work and the relations with local population and park administration. These strategies are specialized but not rigid. This field requires physical mobility, mental vivacity and emotional resilience of the 
primatologist and also the constant support of mateiro's work.

In the beginning of this paper, we suggested that the primatological work which we accompanied and observed in PECB can be expressed by the word hunting. We also know how polemic is this both from primatological as anthropological point of view. So, to make some things clear we will present some arguments to explain the use of this expression.

The anthropological thought do not have a general definition for hunting because the actions, strategies, techniques and meanings of hunting are deeply related to a determined culture in an specific context. There are some regional similarities as, for example, the comparison among hunting practices of people of Low Lands of South America (Bechelany 2012) and other regions, but they are related to ecological and sociocultural aspects. Bull (2014) signalizes the empirical complexity of the hunting in Amazon and analyzes the frequent presence of dogs in those practices (Vander Velden 2009, Kohn 2007). It is also necessary to distinguish technical and cosmological aspects of the different kinds of hunting.

Thus, hunting is an activity that integrates economic, technical, spatial, ecological, symbolical and sociocultural particular aspects (Ingold 2000, Lee 1999/1968, 1984/2012, Lima 1996, Bechelany 2012, Moran 1994, Brandão 1983, Queiroz 1983, Souza 1974).

For example, differently from the exhaustive and continuous persecution observed in primatological work among robust capuchin monkeys in PECB, for the Karitiana (Vander Velden 2009) a good hunter is someone that influences the animal to dislocate to the desired direction in a defined place where it will be strategically enclosed. For a caipira, the hunting includes to know the behavior of the animal, to construct traps strategically putted on the floor and to kill with no compassion (Souza 1974).
In fact, there are not only differences among ethnic or cultural groups in relation to the ways of hunting but there is also differences among ways of observing of monkeys in other primatological fieldwork.

Sá (2005), for example, wrote about the research on the Muriquis or Monocarvoeiro monkeys in an other portion of Atlantic Forest (Santo Antônio do Manhuaçu, Minas Gerais State Brazil). According to Sá $(2005,11-12)$, it is only in the first contacts that the researchers need to pursue the monkeys to observe them. After the habituation, working conditions change and starts a new phase of scientific observation. From this moment is no longer necessary to run behind the monkeys all the time.

In PECB this condition of research never happened at least in the fieldwork with robust capuchin monkeys. There are, of course, sleeping times and feeding moments for the monkeys but their duration is relatively short and it varies by seasonality. So, the work is always done by the actions of continuously pursuing to observe the monkeys independently of habituation. The trajectories of the monkeys define the dynamics of every day of work. The primatologist do not controls the situation alone or by himself/herself. Despite this, there is a plan and an objective: follow and observe the monkeys and describe them as precisely as possible. The primatologist needs to expresses a capacity of "continual adaptation to a changing world” (Marx 2006, 92).

The primatologists do not wander aimlessly. They follow a "planned journey towards a desired destination" (Salzman 2001). The primatologists and the mateiros know certain routes used by the monkeys and update this knowledge so that the research moves forward. The routes drawn by the monkeys are influenced by seasonality, risks, dynamics of foraging and atmospheric variations. They are not rigid, but they are also not random. 
The fieldwork depends on a deep relation between local knowledge and scientific knowledge because the dislocation inside the forest, the localization and persecution of robust capuchin monkeys result from a mutual relation between the primatologist and the mateiro. Knowledge, discoveries, animals and people are connected in a singular context that is constituted by the fluid frontiers of the park and the relations among human, monkeys, other beings, places and nature.

The primatologist and mateiro act together and constitute a unit. There is a profound dependency between them in relation to work, to security and to the permanence inside the forest. Both are seriously concerned with the observation of the monkeys and all that is necessary to do this. This is their strength in the field. They comprise a solid and complementary unit. They are different individuals and cultural beings; they also argue, but, when working together inside the forest following the monkeys, they are a unit.

The fieldwork of primatology of observing behaviors in forest wilderness areas is exhaustive and vigorous. It demands perspicacity, tenacity, patience, vigor, concentration, rigor and the capacity to deeply contemplate the ever-changing context. The required effort is enormous and the progress is made in small steps, in the cases when it does come.

The robust capuchin monkeys' behavior data is something very difficult of obtaining: from 5 meters or more above the observers it seems to us like brief signals, tracks and subtle clues.

We defend that the constant presence of the mateiros, who are members of local population influences the way to conduct the research in the day by day. The peasant traditions of tracking an animal are renewed in another context that includes the park, the monkeys, the scientists, the equipment and the rules of administration.

In this process, the mateiro learns new things and also adapts what he already knows from his local culture. At same time, he teaches to primatologist what he knows about nature. The foundation of the park and the presence of scientists affects the local way of life but also the caipira way of life, affects the way of doing primatology in that context.

So animals and humans constitute, in this context and from the perspective of their complex relations, a special cartography and territorial histories (Ingold 2000) that include humans, animals, technology, scientific knowledge, traditions, nature, bureaucracy and politics. But, how the monkeys react to the human practices? The monkeys can learn abilities with other monkeys, but they also can learn with humans in a specific context that includes a portion of nature preserved by human action. This nature is defined by laws, it is protected by bureaucracy and by an administrative structure.

Sontag (2006/1973, 29-30), when thought about photography, suggested that a camera can, metaphorically, kill. According to her, the moment someone "points" a camera and "tightens a trigger" the photo freezes a moment of life, modify it and replace it. Despite this, the more Sontag (2006/1973) reflected on the photo more she revealed about its depths and subtleties. Some decades ago, many of us, with no doubt, could tell something like this about the hard sciences. The scientific data seemed like a photo shot.

It is important to retake the theme of hunting and of killing to affirm that to kill, meaning to interrupt the life, to freeze in time it is not a good form to express the research on animal behavior. Under the influences of caipira culture, and considering the mutual influences between scientists and mateiros, the interaction and the cooperation are good ways to express the primatological work done about robust capuchin monkeys in PECB. But, at same time, it is also important to remember that to register and to quantify, as well as to photograph, are the more common ways of materialization of the knowledge obtained about monkeys' behavior. These ways 
of producing knowledge could be retaken and analyzed in the future.

\section{ACKNOWLEDGMENTS}

To the Laboratório de Estudos Evolutivos e Ecológicos Humanos (LEEEH), Instituto de Biociências/Universidade de São Paulo, Brazil where we have worked together during Eliane post-doctor research (2011-2012). After, and also specially, to Rui S. Sereni Murrieta. To Universidade de Maringá (UEM - Paraná, Brazil) that give good work conditions to make the fieldwork and to Fundação Araucária that funding Eliane post-doctor research. To Patricia Izar, Lucas Peternelli Corrêa dos Santos, Renato Vasconcelos and Mariana Dutra Fogaça who gave us the opportunity to do this field work. This paper was presented in XI Reunión de Antropología del Mercosul em Montevideo Uruguay in 2015. We are grateful for all members of Trama de Estudios de las Interaciones Animales (TEIA) and specially to Felipe Vander Velden, Martha Ramirez-Gálvez, Celeste Medrano and Andrea Osorio for their sensible, creative and consistent contributions. Also to the young Rafael Velasquez who suggested the book of Susan Sontag and left us so early. To the two peers reviewers of AABC who offered great and the opportunity to rethink about this manuscript.

Jim Henson (www.academicenglishsolutions. com) made English revision and discuss with us the better way to show ideas and information in English language. To Elisa Munhoz Cazorla who helped us with English revision after the submission.

\section{AUTHOR CONTRIBUTIONS}

Eliane Sebeika Rapchan and Walter Alves Neves participated actively together in elaboration of conceptualizing, methodology, formal analysis, discussion of results, obtention of funds, administration of project. They also work together in the revision and approbation of final version of manuscript. Rapchan made the fieldwork and produced the ethnographic material. Neves made the supervision of the project.

\section{REFERENCES}

ALFARO JWL ET AL. 2012. Anointing variation across wild capuchin populations: a review of material preferences, bout frequency and anointing sociality in Cebus and Sapajus. Am J Primatol 74(4): 299-314.

ASQUITH P. 2011. Commentary: Of Bonds and Boundaries: What is the Modern Role of Anthropomorphism in Primatological Studies? Am J Primatol 73: 238-244.

BEAUCHAMP TL AND FREY RG. 2011. The Oxford Handbook of Animal Ethics, New York: Oxford University Press.

BICCA-MARQUES JC. 2016. Urbanization (and Primate Conservation). In: Fuentes A (General Editor). The International Encyclopedia of Primates, Oxford: WilleyBlackwell: 1409-1412.

BIRD-DAVID N. 1992. Beyond 'The Original Affluent Society'. A culturalist reformulation. Curr Anthropol 33(1): 25-34.

BRANDÃO CR. 1983. Os caipiras de São Paulo. São Paulo: Brasiliense, $92 \mathrm{p}$.

BRASIL. 2007. Presidência da República. Decreto n. 6.040, de 07 de fevereiro de 2007. Institui a Política Nacional de Desenvolvimento Sustentável dos povos e Comunidades Tradicionais. Diário Oficial [da] República Federativa do Brasil, Brasília, fev. 2007. Disponível em: <http://www. planalto.gov.br/ccivil_03/_ato2007-2010/2007/decreto/ d6040.htm>. Acesso em: 21 jun. 2018.

BULL P. 2014. Entre a floresta e o doméstico: os cães e os índios da Amazônia. In: Anais XII Semana de Ciências Sociais da UFSCar: 570-580.

CARRITHERS M, BRACKEN LJ AND EMERY S. 2011. Can a Species Be a Person? A Trope and Its Entanglements in the Anthropocene Era. Curr Anthropol 52(5): 661-685.

CARTMILL M. 1993. A View to a Death in the Morning: Hunting and Nature Through History, Cambridge, MA: Harvard University Press.

DAHLES H. 1993. Game Killing and Killing Games: An Anthropological Looking at Hunting in a Modern Society. Soc Anim 1(2): 169-184.

DE DAVID C. 2017. Antropologia das Populações Rurais [e-book]. Santa Maria: UFSM, NTE, UAB.

DELEUZE G AND GUATTARI F. 1980. Mille plateaux. Capitalisme et schizophrénie, Paris: Éditions de Minuit.

DELVAL I, PRESOTTO A, TOKUDA M AND IZAR P. 2017. Cap. 8. Weather Conditions Generally Do Not Affect Navigation Patterns of Sapajus nigritus. In: Luna V, Gonçalves R and Oliveira MAB. A Primatologia no Brasil, Recife: Ed. UFPE 14: 46-65. 
DESCOLA P. 1975. Pourquoi les animaux parfaits, les hybrides et les monstres sont-ils bons à penser symboliquement? L'Homme 15(2): 5-34.

DE WAAL FBM, DINDO M, FREEMAN CA AND HALL MJ. 2005. The monkey in the mirror: Hardly a stranger. PNAS 102(32): 11140-11147.

DURHAM ER. 2003. Chimpanzés também amam: a linguagem das emoções na ordem dos primatas. Rev Antropol 46(1): 85-154.

DURKHEIM E. 1912/1989. As formas elementares da vida religiosa. São Paulo: Paullus Editora.

ELIASON SL. 2008. A Statewide Examination of Hunting and Trophy Nonhuman Animals: Perspectives of Montana Hunters. Soc Anim 16(3): 256-278.

EVANS-PRITCHARD EE. 1969/1940. The Nuer: A Description of the Modes of Livelihood and Political Institutions of a Nilotic People. New York/Oxford: Oxford University Press.

FERREIRA PR. 2008. O texto brasileiro sobre o rural. Eterno retorno ao mesmo? Ruris 2(1): 129-153.

FOGAÇAMD. 2009. Comportamento alimentar e propriedades físicas dos alimentos consumidos por macacos-prego (Sapajus nigritus), no Parque Estadual Carlos Botelho, SP. Master Degree Dissertation, Instituto de Psicologia, Universidade de São Paulo, Brazil. (Unpublished).

GALETTI M AND PEDRONI F. 1994. Seasonal diet of capuchin monkeys (Cebus apella) in a semi-deciduous forest in south-east Brazil. J Trop Ecol 10(1): 27-39.

GAMBORG C, JENSEN FS AND SANDØE P. 2018. Killing Animals for Recreation? A Quantitative Study of Hunters' Motives and Their Perceived Moral Relevance. Soc Natur Resour 31(4): 489-502.

GONZÁLEZ-ABRISKETA O AND CARRO-RIPALDA S. 2016. La apertura ontológica de la antropología contemporânea. Rev Dialect Trad Pop 71(1): 101-128.

GOODALL J. 1971/2010. In the shadow of a man. New York: Mariner Books.

GRUBER T, MULLER MN, STRIMLING P, WRANGHAM R AND ZÜBERBÜLER K. 2009. Wild Chimpanzees Rely on Cultural Knowledge to Solve an Experimental Honey Acquisition Task. Curr Biol 19(21): 1806-1810.

GRUEN L. 2011. Ethics and Animals: An introduction. New York: Cambridge University Press. $1^{\text {st }}$. ed., 250 p.

HARRIS M. 1989. Cows, Pigs, Wars and Witches. The Riddles of Culture. New York: Vintage Books.

HOERIG KA. 2017. Nimrod: Lutheran Pastor/Hunters in Texas. Stud Relig / Sci Relig 46(4): 568-583.

IBGE- INSTITUTO BRASILEIRO DE GEOGRAFIA E ESTATÍSTICA. Censo. 2010. http://www.censo2010.ibge. gov.br.

INGOLD T. 1994. Humanity and Animality. In: Ingold T (Ed), Companion Encyclopedia of Anthropology, Londres: Routledge: 14-32.
INGOLD T. 2000. The Perception of the Environment: Essays on livelihood, dwelling and skill, Londres: Routledge, $1^{\text {st }}$. ed., $480 \mathrm{p}$.

INGOLD T. 2001. From the transmission of representations to the education of attention. In: Whitehouse $\mathrm{H}$ (Ed), The debated mind: evolutionary psychology versus ethnography, Oxford: Berg: 113-153.

INGOLD T. 2004. Introduction. Anthropology after Darwin. Social Anthropology 12(2):177-179.

INGOLD T. 2011. Being Alive. Essays on movement, knowledge and description. New York: Routledge, $270 \mathrm{p}$.

IZAR P, VERDERANE P, SANTOS LP, MENDONÇAFURTADO O, PRESOTTO A, TOKUDA M, VISALBERGHI E AND FRAGASZY D. 2012. Flexible and conservative features of social systems in tufted capuchin monkeys: comparing the socioecology of Sapajus libidinosus and Sapajus nigritus. Ame J Primatol 74(4): 315-331.

KOHN E. 2007. How dogs dream: Amazonian natures and the politics of transspecies. Am Ethnol 34(1): 3-24.

KWON H. 1998. The Saddle and the Sledge: Hunting as Comparative Narrative in Siberia and Beyond. JRAI 4(1): 115-127.

LATOUR B. 1994/2008. Jamais fomos modernos. São Paulo: Ed. 34,157 p.

LEACH E. 1964. Anthropological Aspects of Language: Animal Categories and Verbal Abuse. Massachussets: MIT Press.

LEE RB AND DEVORE I (Eds). 1968/1999. Man, the hunter. New York: Aldine de Gruyter.

LEE RB. 1992. Art, science, or politics? The crisis in huntergatherer studies. American Anthropologist 94(1): 31-54.

LESTEL D. 2008. Les communautés hybrides. Sciences Humaines 6(194): 8.

LESTEL D. 2014. Epistemological interlude, Angelaki: Journal of Theoretical Humanities 19(3): 151-160.

LÉVI-STRAUSS C. 1968. The Savage Mind. New York: University of Chicago Press.

LÉVI-STRAUSS C. 1963/1974. Structural Anthropology, New York: Basic Books. Transl. Claire Jacobson and Brooke G. Schoepf, 440 p.

LÉVI-STRAUSS D. 1962. Le Totemisme Aujourd'hui. Paris: PUF. Coléction Mythes et Religions, 159 p.

LIENHARDT G. 1978. Divinity and Experience: the religion of the Dinka. Oxford: Oxford University Press.

LIMA MGM ET AL. 2017. Capuchin monkey biogeography: understanding Sapajus Pleistocene range expansion and the current sympatry between Cebus and Sapajus. J Biogeogr 44(4): 810-820.

LIMA TS. 1996. O dois e seu múltiplo: Reflexões sobre o perspectivismo em uma cosmologia tupi. Mana 2(2): 2147. 
MARX E. 2006. Tribal Pilgrimages to Saints' Tombs in South Sinai. In: Levy TE (Ed), Archaeology, Anthropology and Cult: The Sanctuary at Gilat, Israel, London: Equinox, p. 54-74.

MORAN EF. 1994. Adaptabilidade Humana. uma introdução à antropologia ecológica, São Paulo: Edusp, 445 p.

MOURA MM. 1978. Os herdeiros da terra: parentesco e herança numa área rural, São Paulo: Hucitec, 100 p.

NAKAI ES. 2007. Fissão-fusão em Cebus nigritus: Flexibilidade Social com Estratégia de Ocupação de Ambientes Limitantes. Master Dissertation, Instituto de Psicologia, Universidade de São Paulo, Brasil. (Unpublished).

PRESOTTO A. 2009. Mapas Cognitivos de Primatas: Análise de Movimentos e Rotas de Cebus nigritus apoiada por sistemas de Informação Geográfica. PhD Thesis, Departamento de Geografia, Faculdade de Filosofia Letras História e Ciências Sociais, Universidade de São Paulo, Brasil.

PRESOTTO A AND IZAR P. 2010. Spatial reference of black capuchin monkeys in Brazilian Atlantic Forest: egocentric or allocentric? Anim Behav 80(1): 125-132.

QUEIROZ MIP. 1973. O campesinato brasileiro: ensaios sobre civilização e grupos rústicos no Brasil, Petrópolis: Vozes, $242 \mathrm{p}$.

QUEIROZ RS. 1983. Caipiras negros no Vale do Ribeira, São Paulo: Edusp, 136 p.

RAPCHAN ES. 2016. Casas, espaços públicos e parques o caso entre os macacos-prego e a cidade em Maringá. Iluminuras 17(42): 350-371.

RAPCHAN ES AND NEVES WA. 2005. Chimpanzés não amam! Em defesa do significado. Rev Antropol 48(2): 649-698.

RAPCHAN ES AND NEVES WA. 2016. Famílias híbridas: camponeses, primatólogos e macacos-prego no cerrado piauiense. Teor Cult 11(2): 107-117.

RAPPAPORT R. 1968/2000. Pigs for the Ancestors: Ritual and Ecology of a New Guinea People. Illinois: Waveland Press, $501 \mathrm{p}$.

RÄSÄNEN T AND SYRJÄMAA T (Eds). 2017. Shared lives of Humans and Animals. Animal Agency in the Global North. New York: Routledge. $1^{\text {st }}$ ed., 212 p.

RIBEIRO LMP. 2008. Mapeamento do protestantismo rural no lençol de cultura caipira brasileiro. Cad CERU 19(2): 113-128.

SÁ GJS. 2005. 'Meus macacos são vocês': Um antropólogo seguindo primatólogos em campo, Anthropológicas 16(2): 41-66.

SAGAN C. 1997. The Demon-Haunted World: Science as a Candle in the Dark, New York: Ballantine Books. 459 p.

SAHLINS M. 1979. La pensée bugeoise: a sociedade ocidental enquanto cultura. In: Cultura e Razão Prática, Rio de Janeiro: Zahar: 190-199.
SALZMAN CP. 2001. Understanding Culture: An Introduction to Anthropological Theory, Illinois/Waveland: Prospect Heights. $1^{\text {st }}$ ed., 173 p.

SANTOS BS. 1998. Um discurso sobre as ciências na transição para uma ciência pós-moderna. Estudos Avançados 2(2): 46-71.

SANTOS LPC. 2011. Parâmetros nutricionais da dieta de duas populações de macacos-prego: comparação entre Mata Atlântica (Cebus nigritus) e ecótono Cerrado/ Caatinga (Cebus libidinosus). PhD Project, Departamento de Psicologia Comportamental, Instituto de Psicologia, Universidade de São Paulo, Brasil.

SILVEIRA FLA. 2016. Cap. 13. As relações humanas e nãohumanos na metrópole amazônica. Estudo etnográfico no Bosque Rodrigues Alves, Belém (PA). In: Bevilaqua $\mathrm{CB}$ and Velden FV (Orgs), Parentes, vítimas, sujeitos: perspectivas antropológicas sobre relações entre humanos e animais. São Carlos/Curitiba: EdUFSCar/Ed.UFPR: 285-314.

SMUTS BB. 1999. Sex and friendship in baboons, London: Aldine Transaction. $1^{\text {st }}$ ed., $336 \mathrm{p}$.

SPAGNOLETTI N, VISALBERGHI E, VERDERANE M, OTTONI E, IZAR P AND FRAGASZY D. 2012. Stone tool use in wild bearded capuchin monkeys (Cebus libidinosus). Is it a strategy to overcome food scarcity? Anim Behav 83: 1285-1294.

SONTAG S. 2006/1973. Sobre la fotografía, Mexico: Alfaguara. Trad. Carlos Gardiní, 290 p.

TALEBI MG AND LEE PC. 2010. Activity Patterns of Southern Muriquis (Brachyteles arachnoides) in the last continuous remnant of Brazilian Atlantic Forest. Int $\mathrm{J}$ Primatol 31: 571-583.

SOUZA ACM. 1974. Os parceiros do Rio Bonito, São Paulo: Duas Cidades, $284 \mathrm{p}$.

TAMBIAH SJ. 1969. Animals are Good to Think About and Good to Prohibit. Ethnology 8(4): 423-459.

TOLA FC. 2016. "Giro ontológico" y la relación naturaleza/ cultura. Reflexiones desde el Gran Chaco. Apuntes de Investigación del CECYP 27: 113-128.

VANDER VELDEN FF. 2009. Sobre cães e índios: domesticidade, classificação zoológica e relação humanoanimal entre os Karitiana. Rev Antropol 25(1): 124-144.

VARELA SAG. 2015. Antropología y el estudio de las ontologías a principios del siglo XXI: sus problemáticas y desafíos para el análisis de la cultura. Estudios sobre las Culturas Contemporáneas XXI (42): 39-64.

WIAFE EW. 2018. Hunted species and hunting equipment used by rainforest poachers in Ghana, Journal of Threatened Taxa. Short Communication. Building evidence for conservation globally 10(2): 11271-11284. 